\title{
Growth Opportunities, Capital Structure and Dividend Policy in Emerging Market: Indonesia Case Study
}

\author{
Nevi DANILA ${ }^{1}$, Umara NOREEN ${ }^{2}$, Noor Azlinna AZIZAN ${ }^{3}$, Muhammad FARID ${ }^{4}$, Zaheer AHMED ${ }^{5}$
}

Received: July 25, 2020 Revised: August 23, 2020 Accepted: September 03, 2020

\begin{abstract}
The objective of the study is to investigate the effect of growth opportunities on capital structure and dividend policy in Indonesia. The study employs panel data of companies listed on Indonesia Stock Exchange that distribute dividends from 2007 to 2017. Fixed and random effect regression models are used. Findings based on growth opportunities on capital structure and dividend policy in Indonesia are in line with the existing theory (i.e., contracting theory). Growth opportunities have a significant negative correlation with debt ratio and dividend yield, which suggests that firms with high growth opportunities are discouraged to generate debt to resolve underinvestment and asset-substitution problem. Firms with more investment opportunities tend to adopt a low dividend payout policy because the cash flows will be used up for investment. The positive impact of firm size on leverage is due to the low bankruptcy risk and cost of a large company. Profitability has a positive impact on the dividend policy because profitable companies can reserve larger free cash flows and, thus, pay higher dividends. The positive influence of ownership on leverage is interpreted by the unwillingness of majority stockholders to commit to equity financing in order to avoid reducing the ownership and preserve control of the company.
\end{abstract}

Keywords: Growth Opportunities, Capital Structure, Dividend, Emerging Market, Leverage

JEL Classification Code: G32, G35, G30

\section{Introduction}

This study on dividend policy and structure of capital is conducted to confirm the firm theory. Capital structure theory refers to the composition of equity and debt used

${ }^{1}$ First Author and Corresponding Author. Associate Professor, College of Business Administration, Prince Sultan University, Saudi Arabia [Postal Address: P.O. Box No. 66833, Rafha Street, Riyadh 11586, Kingdom of Saudi Arabia] Email: ndanila@psu.edu.sa

${ }^{2}$ Assistant Professor, College of Business Administration, Prince Sultan University, Riyadh, Kingdom of Saudi Arabia. Email: Unoreen@psu.edu.sa.

${ }^{3}$ Professor, College of Business Administration, Prince Sultan University, Riyadh, Kingdom of Saudi Arabia.

Email: naziza@psu.edu.sa.

${ }^{4}$ Research Scholar, STIE Malangkucecwara, Malang, Indonesia. Email: muhammadfarid48@yahoo.com

${ }^{5}$ Assistant Professor, Department of Business Administration, Iqra

University Karachi, Pakistan. Email: z4zaheer.ahmed@gmail.com.

(c) Copyright: The Author(s)

This is an Open Access article distributed under the terms of the Creative Commons Attribution Non-Commercial License (https://creativecommons.org/licenses/by-nc/4.0/) which permits unrestricted non-commercial use, distribution, and reproduction in any medium, provided the original work is properly cited.
onrestricted non-commerial for financing business activities. Research evidence shows that several factors influence capital structure and dividend policy (i.e., growth opportunities). Some studies argue that negative relationships exist between opportunities for growth and dividend yields and debt levels (Alonso et al., 2005; Gul, 1999). Moreover, a study conducted in Russia concluded that growth opportunity has a negative impact on leverage (Ilyukhin, 2017). However, other studies suggested that the influence of growth opportunity on dividend yield is zero (Issa, 2015).

The current research examines the impact of growth opportunities on capital structure and dividend policy from the perspective of companies trading on Indonesia Stock Exchange (IDX). This study focuses on Indonesia, the biggest economy in Southeast Asia, since relatively little research has examined the impact of growth opportunities on capital structure and dividend policy. Moreover, the findings are inconsistent. Abbas et al. (2011); Bulan and Sanyal (2005); Chen (2002); Abbas et al. (2016); Balboa et al. (2012); Lious et al. (2015) suggested that growth opportunities significantly affect capital structure. The research conducted by Ilyukhin (2017) and Indrajaya et al. (2011) suggested that growth 
opportunities do not have any significant effect on capital structure. Abor and Bokpin (2010); Amidu and Abor (2006); de Andrés Alonso et al. (2005); Ghosh and Sun (2014); Jabbouri (2016) argued that there is evidence of the impact of growth opportunities on dividend policy. In contrast, Issa (2015) and Ressy and Chariri (2013) found that dividend policy is not affected by the growth opportunities.

The norms of dividend policy in emerging markets are implemented differently from the developed countries. A noticeable difference is that emerging markets give high emphasis on dividend payout ratios; consequently, dividend payments in emerging markets tend to fluctuate more than in developed markets (Glen, Karmokolias, Miller, and Shah, 1995). Baker and Powell (2012) argued that the earnings stability and the current and expected future earnings level mostly determine the dividend policy in Indonesia.

From the above explanation, investigating the effect of growth opportunities on the capital structure and dividend policy in Indonesia is essential. The current study contributes to the extant literature by focusing on the emerging market of Indonesia, which has the biggest national economy in Southeast Asia.

\section{Literature Review}

Myers (1977) defines growth opportunities as a part of firm value, which depends on discretionary future expenditure by a firm; future investment and variable costs, which boost the value of firm, are included. It depends on the assets in place and the sunk cost. Thus, it should be financed by more leverage than growth opportunities, and substantial debt financing should be associated with capital-intensity, high operating debt and profitability.

Myint et al. (2018) suggested that the optimal capital structure should incorporate the competitive position of a company, as well as the availability of growth opportunity. Moreover, Smith and Watts (1992) elaborated dividend and compensation policies, investment opportunities and corporate financing. Three theories - tax-based, signalling, and contracting theories - explain the association between investment opportunity set (IOS) and debt and dividend policies. Taxed-based theory suggests a negative association between IOS and leverage. It is based on the argument of tax progressivity, which infers that high fluctuation in taxable income increases expected tax liabilities (Smith \& Stulz, 2006). Growth-option firms have highly volatile cash flows and, thus, have high incentives to decrease the leverage in their capital structure over the range of progressivity (Watts \& Smith, 1992).

Two assumptions are developed by the signalling theory. First, incentive to signal does not exist given the absence of asymmetric information. Thus, asymmetric information induces substantial incentives for signalling. Second is the variety of signalling cost. The costs are less sensitive than the benefits of signalling depending on the variation in the size of asymmetric information. Thus, signalling theory suggests that companies with high growth options have more important asymmetric information, which leads to high leverage. That is, signalling theory forecasts a positive relationship between IOS and leverage (Watts \& Smith, 1992).

Contracting theory argues that firms with high growth opportunities have lower leverage. Firms with risky debt outstanding can reduce the value of shareholders if they undertake a project that has positive net present value because debt holders have a priority claim on the project's cash flows over shareholders. To overcome the underinvestment problem, companies finance the growth with equity rather than leverage (Myers, 1977). Moreover, Jensen et al. (1986) suggest that firms with prominent free cash flow are motivated to have a high level of leverage in their structure of capital due to their credibility in paying out excess cash.

Empirically, only contracting hypotheses show consistent results with the theory (Gaver \& Gaver, 1993; Goyal et al., 2002; Long \& Malitz, 1985; Watts \& Smith, 1992). Following prior studies, the first hypothesis is formulate as follows:

H1. Firms with a higher level of investment opportunity will possess lower debt.

According to contracting theory, firms with high growth options have less dividend payments. The cash flow of firms shows a negative connection between dividend policy and investment. The higher the amount of investment in a given period, the smaller the dividend. The reason is that firms with more growth opportunities have low free cash flow and consequently pay low dividends (Jensen, 1986). The newissue market reduces cost of agency by ensuring effective monitoring. When few growth choices exist, firms will opt for few new-issue markets and forgo this benefit if they compensate with less dividends (Easterbrook, 1984; Rozeff, 1982). Moreover, CEOs' business strategies determine the payments of dividends. In other words, CEO overconfidence has a significant role in dividend payment policy. Hoang et al., (2020) suggest that CEO overconfidence has dividend yield higher than CEO non-overconfidence. The authors also argued that the non-state enterprise coupled with CEO overconfidence influence significantly dividend yield without affecting other types of enterprises. Tahir et al. (2020) proposed that there is a positive correlation between the average age of board members, the size of corporate board, the tenure of board, and dividend payout policy. On the other hand, there is no correlation between duality of CEO, diversity of board members, board independence, and dividend payout policy. 
The underinvestment problem is reduced when dividend covenants impose a minimum investment requirement due to a maximum dividend payout specification. Thus, firms with high growth choices can allow more constrains on dividends; that is, these firms are expected to have low dividends (Watts \& Smith, 1992). Empirically, the finding is consistent with the contracting argument (Abor \& Bokpin, 2010; Amidu \& Abor, 2006; Collins et al., 1996; Gaver \& Gaver, 1993; Gul \& Kealey, 1999; Lloyd et al., 1985).

The signalling hypothesis suggests that high-quality firms compensate high dividends (Bhattacharya, 1979). Firms with greater asymmetry information should pay higher dividends. The evidence is consistent with the contracting hypothesis but does not support the signalling hypothesis (Gaver \& Gaver, 1993; Watts \& Smith, 1992). The second hypothesis is formulated as follows:

H2. Firms with higher levels of growth opportunities keep lower dividends.

Size of firms is expected to have a negative association with the equity-to-value ratio. If the cost of financial distress reduces leverage, then the great diversification of bigger firms allows them to have more debt than smaller firms (Watts \& Smith, 1992).

Moreover, according to trade-off theory, the size of the company has a positive relationship with leverage ratio. Bigger firms have smaller the risk of bankruptcy and relatively smaller bankruptcy cost. Furthermore, larger firms have smaller agency costs of leverage, smaller costs of monitoring, less fluctuation cash flows, and more convenient access to the credit market; they also benefit from the tax shield (Deesomsak et al., 2004).

The pecking-order theory presumes that managers favor to fund projects internally because of the informational asymmetry between managers and external investors. Moreover, profitable companies tend not to raise external equity in order to avoid the possible dilution of ownership. Therefore, a negative correlation exists between profitability and debt.

Regarding dividend policy, profitability and size have a positive impact on dividend payout. Firms that have larger profits and bigger size pay more dividends (Al-Malkawi, Al-Malkawi, Rafferty, \& Pillai, 2010; Brawn \& Ševi, 2018; Maldajian \& El Khoury, 2014).

\section{Data and Methodology}

The sample in this study consists of listed companies that distribute dividends in IDX from 2007 to 2017. The year 2007 is selected because it is when two IDXs merged. Only 14 out of 626 companies in IDX have been distributing dividends for 11 years.
The dependent variables are capital structure and dividend policy. Capital structure is measured using the debt/equity ratio. Dividend policy is measured using two indicators, namely, dividend payout and yield ratios. Three proxies are used for IOS, namely, the market/book value of assets (MBA), market/book value of equity (MBE) and earnings/price (EP) ratio (Beaver \& Morse, 1978; Chung \& Charoenwong, 1991; French et al., 1991). The control variables are total assets (TA), profitability $(P)$ and ownership $(O)$. Ownership is divided into domestic and foreign companies. The definition of each variable is described below.

- Capital structure: book debt/equity ratio is defined as total book value of debt/total book value of equity. Market debt/equity ratio is defined as total book value of debt/market value of equity.

- Dividend policy: dividend payout is defined as (dividends/primary earnings before extraordinary item): shares outstanding. Dividend yield is defined as (dividends /price): shares outstanding.

- IOS: MBA is defined as (book value of assets - total equity + share outstanding $\times$ share price)/book value of assets. MBE is defined (shares outstanding $\times$ share price)/book value of equity. EP ratio is defined as primary EPS before extraordinary item/share price.

Given that the data are unbalanced panel (pooled) data, we initially used the random-effect model (REM), which is consistent even if the true model is a pooled estimator. Then, the Hausman test is used to examine whether the REM is an appropriate model. A significant Hausman test means that the REM is not appropriate; then, a two-way fixed effects model (FEM) is employed, which allows for individual heterogeneity and time effects and provides robust heteroskedasticity autocorrelation (HAC) standard errors (Gujarati \& Porter, 2009).

\section{Results and Discussion}

\subsection{Summary Statistics}

Table 1 shows the details of all variables' summary statistics. Looking at the debt/equity ratio, the average ratio of the companies is more than 1 , which indicates that the company has undertaken more debt than it has issued share capital to finance its operations. The probability of bankruptcy is high. Moreover, the debt/equity market value shows an even higher ratio, which suggests that the market views the value of the companies as lower than the book value of equity. Moreover, increased financial openness to international markets is linked to high leverage ratios (Mitton, 2008). 
Table 1: Summary Statistics

\begin{tabular}{|l|c|c|c|c|}
\hline Variables & Mean & Minimum & Maximum & Standard deviation \\
\hline MBA & 2.0126 & 0.30053 & 34.942 & 4.1215 \\
\hline MBE & 3.2537 & 0.0028358 & 71.792 & 9.2199 \\
\hline EP & 2074.7 & 0.090000 & 55576. & 6404.1 \\
\hline Book debt/equity ratio & 1.5317 & 0.20883 & 9.6647 & 1.8845 \\
\hline Market debt/equity ratio & 10.408 & 0.012406 & 181.49 & 25.785 \\
\hline Payout & 0.34715 & 0.00070000 & 0.99930 & 0.25791 \\
\hline Yield & 0.038342 & 0.00010000 & 0.34300 & 0.060897 \\
\hline TA & $5.2748 \mathrm{e}+007$ & $2.2644 \mathrm{e}+005$ & $7.3988 \mathrm{e}+008$ & $1.3078 \mathrm{e}+008$ \\
\hline P & 7.0123 & 0.020000 & 42.070 & 10.626 \\
\hline
\end{tabular}

Table 2: Regression Results for IOS on Capital Structure I

\begin{tabular}{|c|c|c|}
\hline \multicolumn{3}{|c|}{$\begin{array}{l}\text { Model: Fixed-effects* } \\
\text { Dependent variable: Book debt/equity ratio } \\
\text { Sample: } 151 \text { observations } \\
\text { Robust (HAC) standard errors }\end{array}$} \\
\hline Variables & Coefficients & P-value \\
\hline Constant & -3.10184 & $<0.0001^{* * *}$ \\
\hline MBA & 0.210125 & 0.1657 \\
\hline MBE & -0.0882952 & 0.1211 \\
\hline EP & 0.0337767 & 0.3856 \\
\hline TA & 0.173742 & $<0.0001^{* * *}$ \\
\hline$P$ & 0.142043 & $0.0172^{* *}$ \\
\hline $\mathrm{O}$ & 0.239928 & $0.0432^{* *}$ \\
\hline \multicolumn{3}{|c|}{$\begin{array}{l}\text { REM is performed. Hausman test: Chi-square (6) equals } 34.3173 \text { with a p-value of } 5.84184 \mathrm{e}-006 \text {. Therefore, the GLS estimates are } \\
\text { inconsistent. REM is not the appropriate model. } \\
{ }^{* *} \text { significant at the } 1 \% \text { level and }{ }^{* *} \text { significant at the } 5 \% \text { level }\end{array}$} \\
\hline
\end{tabular}

The average dividend payout ratio is consistent with the average dividend payout ratio of emerging companies (35\%), which will be stable in the next few years according to the Negyal manager of JP Morgan Asset Management (Walker, 2019).

\subsection{Regression Results}

\subsubsection{IOS on Capital Structure}

The result of the Hausman test on the random-effects (regression) model is significant for both regression models. Therefore, REM is inconsistent, and FEM is the preferred model. The results are shown in Table 2 and Table 3.

The IOS proxy does not have an impact on book debt/equity ratio as a capital structure proxy. However, only the growth proxy (i.e. market/book value of equity) affect negatively on the market debt/equity ratio as a capital structure proxy. This result is consistent with the contracting theory. It suggests that firms with high growth opportunities are discourage to issue debt for two justifications, namely, underinvestment and assetsubstitution problem (Abor \& Bokpin, 2010; Amidu \& Abor, 2006; Collins et al., 1996; Gaver \& Gaver, 1993; Gul \& Kealey, 1999; Lloyd et al., 1985). In addition, Mukhibad et al. (2020) supported the finding that investment opportunity (IOS) has a negative impact on debt policy in Indonesian manufacture companies. The companies more rely on internal resources for funding the investment. The same outcome of a negative correlation between investment opportunities and debt/equity ratio is proposed by Vijayakumaran and Vijayakumaran (2019). Furthermore, the percentage of short-term debt mitigates the negative impact of investment opportunities on leverage. However, the effect is only significant to the private controlled companies in China. 
Table 3: Regression Results for IOS on Capital Structure II

\begin{tabular}{|c|c|c|}
\hline \multicolumn{3}{|c|}{$\begin{array}{l}\text { Model: Fixed-effects* } \\
\text { Dependent variable: Market debt/equity ratio } \\
\text { Sample: } 151 \text { observations } \\
\text { Robust (HAC) standard errors }\end{array}$} \\
\hline Variables & Coefficients & P-value \\
\hline Constant & -3.10184 & $<0.0001^{* * *}$ \\
\hline MBVA & 0.210125 & 0.1657 \\
\hline MBVE & -1.08830 & $<0.0001^{* * *}$ \\
\hline EP & 0.0337767 & 0.3856 \\
\hline TA & 0.173742 & $<0.0001^{* * *}$ \\
\hline $\mathrm{P}$ & 0.142043 & $0.0172^{* *}$ \\
\hline $\mathrm{O}$ & 0.239928 & $0.0432^{* *}$ \\
\hline
\end{tabular}

Table 4: Regression Results for IOS on Dividend Policy I

\begin{tabular}{|c|c|c|}
\hline \multicolumn{3}{|c|}{$\begin{array}{l}\text { Model: Fixed-effects } \\
\text { Dependent variable: Dividend payout } \\
\text { Sample: } 151 \text { observations } \\
\text { Robust (HAC) standard errors } \\
\text { Omitted due to exact collinearity: Ownership (O) }\end{array}$} \\
\hline Variables & Coefficients & P-value \\
\hline Constant & 1.62770 & 0.8291 \\
\hline MBA & -0.722040 & 0.1962 \\
\hline MBE & 0.408959 & 0.1149 \\
\hline EP & -0.0876846 & 0.4210 \\
\hline TA & -0.158497 & 0.7317 \\
\hline$P$ & 0.223415 & $0.0645^{*}$ \\
\hline
\end{tabular}

Moreover, all the control variables (i.e., firm size, profitability, and dummy ownership $[1=$ domestic, $0=$ foreign]), are significantly related to market debt/equity ratio. The positive relationship between firm size and leverage ratio is consistent with the trade-off theory. The relationship between a company's size and leverage ratio is positive because of the low bankruptcy risk and cost of a large company (Deesomsak et al., 2004). However, the finding is contradictory to Mukhibad et al. (2020); the authors argued that the size of firms and profitability do not have any impact of the debt policy for public companies in Indonesia. It means that high profitability companies are not necessarily having higher debt ratio in their capital structure.

Furthermore, the positive correlation of profitabilityto-debt ratio is because more profitable companies tend to have more advantages of tax shield (Pettit \& Singer,
1985). However, such a correlation is contradictory to the pecking-order theory. The company prefers to finance itself first internally through retained earnings. The exclusive ownership view in the emerging market and Indonesia has a big effect on the debt financing of companies. The positive association result in this research can be interpreted by the unwillingness of majority stockholders to commit with equity financing in order to avoid reducing the ownership and preserve control of the company (Haron, 2018).

\subsection{IOS on Dividend Policy}

The result of the Hausman test on the random-effect (regression) model is not significant for both of the regressions models. Thus, REM is the appropriate model (see Table 4 and Table 5). 
Table 5: Regression Results for IOS on Dividend Policy II

\begin{tabular}{|c|c|c|}
\hline \multicolumn{3}{|c|}{$\begin{array}{l}\text { Model: Fixed-effects } \\
\text { Dependent variable: Dividend yield } \\
\text { Sample: } 151 \text { observations } \\
\text { Robust (HAC) standard errors } \\
\text { Omitted due to exact collinearity: Ownership (O) }\end{array}$} \\
\hline Variables & Coefficients & P-value \\
\hline Constant & 0.948988 & 0.8863 \\
\hline MBA & -0.698543 & $0.0832^{*}$ \\
\hline MBE & 0.285146 & 0.1476 \\
\hline EP & 0.162496 & 0.1206 \\
\hline TA & -0.377216 & 0.3577 \\
\hline $\mathrm{P}$ & 0.172267 & 0.1946 \\
\hline
\end{tabular}

Growth opportunity proxies are not significantly related to the dividend policy that uses payout as a proxy. However, only one of the growth opportunity proxies has a significant negative impact on the dividend policy with yield as a proxy. The result is consistent with the existing literature. Firms with investment opportunities are most likely to pursue a low dividend payout policy because the cash flows will be used up for the investment (Abor \& Bokpin, 2010; Amidu \& Abor, 2006; Watts \& Smith, 1992). Nevertheless, Tahir and Mushtaq (2016) suggested that investment opportunities, managerial ownership and liquidity did not have any significant correlation with dividend payout for oil and gas companies in Pakistan. Moreover, firm size does not have an impact on the dividend policy. Therefore, the size of firms in Indonesia is irrelevant to the dividend policy, which is reflected by the fact that only $2.2 \%$ (14 out of 626) of the listed company distribute dividends regularly.

Moreover, profitability has a significant positive correlation with dividend payout. Profitable companies with high stable net earnings can secure more significant free cash flows and compensate higher dividends. Several studies support the positive association between dividend payments and earnings, especially in emerging markets (Ahmed \& Javid, 2009; Al-Twaijry, 2007; Jabbouri, 2016). Firms with increase in profitability generally increase dividend payments; for example, study on the Indian market argues the positive impact of a current year profit on a dividend policy adoption (Qamar \& Ahmed Bazaz, 2014). In addition, managers of Indonesian firms argue that the stability of earnings and the level of current and forecasting future earnings are the most significant factors of dividends (Baker \& Powell, 2012)

\section{Conclusion}

This study on growth opportunities on the capital structure and dividend policy in the emerging market in Indonesia provides findings that are consistent with the existing theory (i.e., contracting theory). Growth opportunities have a significantly negative correlation with debt ratio and dividend yield. Such correlation suggests that firms with high growth opportunities are discouraged to issue debt for two reasons, namely, underinvestment and asset-substitution problem. Moreover, firms with more investment opportunities tend to adopt a low dividend payout policy because the cash flows will be used up for the investment.

Furthermore, firm size and profitability as control variables have a significant impact on capital structure and dividend policy. The positive impact of firm size on leverage is because of the low bankruptcy risk and cost to a large company. In addition, the positive correlation of profitabilityto-debt ratio is because highly profitable companies tend to have more advantages of the tax shield.

Profitability has a positive impact on the dividend policy because profitable companies with high stable net earnings can reserve larger free cash flows and thus pay higher dividends. The positive influence of ownership on leverage is because of unwillingness of majority stockholders to commit with equity financing in order to avoid reducing the ownership and preserve control of the company.

\section{References}

Abbas, A., Hashmi, S. H., \& Chishti, A. (2016). Dividend Policy and Capital Structure: Testing Endogeneity. In: SSRN Electronic Journal. https://doi.org/10.2139/ssrn.2745726 
Abor, J., \& Bokpin, G. A. (2010). Investment opportunities, corporate finance, and dividend payout policy: Evidence from emerging markets. Studies in Economics and Finance, 27, 180-194.

Ahmed, H., \& Javid, A. Y. (2009). The determinants of dividend policy in Pakistan. International Research Journal of Finance and Economics, 29, 110-125. https://mpra.ub.uni-muenchen. $\mathrm{de} / \mathrm{id} / \mathrm{eprint} / 37339$

Al-Malkawi, H. -A. N., Al-Malkawi, H. -A. N., Rafferty, M., \& Pillai, R. (2010). Dividend Policy: A Review of Theories and Empirical Evidence. International Bulletin of Business Administration, 9, 171-200. http://www.eurojournals.com

Al-Twaijry, A. A. (2007). Dividend policy and payout ratio: evidence from the Kuala Lumpur stock exchange. The Journal of Risk Finance, 8(4), 349-363. https://doi.org/https://doi. org/10.1108/15265940710777306

Amidu, M., \& Abor, J. (2006). Determinants of dividend payout ratios in Ghana. Journal of Risk Finance, 7(2), 136-145. https:// doi.org/10.1108/15265940610648580

Andrés Alonso, P., López Iturriaga, F. J., \& Rodríguez Sanz, J. A. (2005). Financial decisions and growth opportunities: A Spanish firm's panel data analysis. Applied Financial Economics, 15(6), 391-407. https://doi.org/10.1080/09603100500039201

Baker, H. K., \& Powell, G. E. (2012). Dividend policy in Indonesia: Survey evidence from executives. Journal of Asia Business Studies, 6(1), 79-92. https://doi. org/10.1108/15587891211191399

Balboa, M., Martí, J., \& Tresierra-Tanaka, Á. E. (2012). Capital Structure Determinants In Growth Firms Accessing Venture Funding. In: The Oxford Handbook of Venture Capital. https:// doi.org/10.1093/oxfordhb/9780195391596.013.0011

Beaver, W., \& Morse, D. (1978). What determines price-earnings ratios? Financial Analysts Journal, 34(4), 65-76.

Bhattacharya, S. (1979). Imperfect Information, Dividend Policy, and "The Bird in the Hand" Fallacy. The Bell Journal of Economics, 10(1), 259-270.

Brawn, D. A., \& Ševi', A. (2018). Firm size matters: Industry sector, firm age and volatility do too in determining which publicly-listed US firms pay a dividend. International Review of Financial Analysis, 58, 132-152.

Bulan, L. T., \& Sanyal, P. (2005). Is There Room for Growth? Debt, Growth Opportunities and the Deregulation of U.S. Electric Utilities. In: SSRN Electronic Journal. https://doi.org/10.2139/ ssrn.867004

Chen, K. K. (2002). The Influence of Capital Structure on Company Value with Different Growth Opportunities. In: SSRN Electronic Journal. https://doi.org/10.2139/ssrn.313960

Chung, K., \& Charoenwong, C. (1991). Investment options, assets in place, and the risk of stocks. Financial Management, 20, 21-33.

Collins, M. C., Saxena, A. K., \& Wansley, J. W. (1996). The Role of Insiders and Dividend Policy: a Comparison of Regulated and Unregulated Firms. Journal of Financial And Strategic Decisions, 9(2), 1-9.

Deesomsak, R.,Paudyal,K., \& Pescetto, G.(2004). The Determinants of Capital Structure: Evidence from the Asia Pacific Region. Journal of Multinational Financial Management, 14(4-5), 387405. https://doi.org/10.1016/j.mulfin.2004.03.001

Easterbrook, F. H. (1984). Two Agency-Cost Explanations of Dividends. The American Economic Review, 74(4), 650-659.

French, K. R., Poterba, J. M., Boyle, D., Brahmbhatt, M., Hayashi, F., Johnson, S., Kesler, D., Sladkus, M., Suzuki, A., Tanabe, T., Tsuji, M., \& Yamaji, H. (1991). Were Japanese stock prices too high? Journal of Financial Economics, 29, 337-363.

Gaver, J. J., \& Gaver, K. M. (1993). Additional evidence on the association between the investment opportunity set and corporate financing, dividend, and compensation policies. Journal of Accounting and Economics, 16(1-3), 125-160.

Ghosh, C., \& Sun, L. (2014). Agency Cost, Dividend Policy and Growth: The Special Case of REITs. Journal of Real Estate Finance and Economics, 48(4), 660-708. https://doi. org/10.1007/s11146-013-9414-3

Glen, J. D., Karmokolias, Y., Miller, R. R., \& Shah, S. (1995). Dividend policy and behavior in emerging markets : to pay or not to pay (No. 1; IFD26).

Goyal, V., Lehn, K., \& Racic, S. (2002). Growth Opportunities and Corporate Debt Policy: The Case of the U.S. Defense Industry. Journal of Financial Economics, 64(1), 35-59.

Gujarati, D., \& Porter, D. (2009). Basic Econometrics (5th ed.). New York, NY: McGraw-Hill Education.

Gul, F. A. (1999). Growth opportunities, capital structure and dividend policies in Japan. Journal of Corporate Finance, 5(2), 141-168. https://doi.org/10.1016/s0929-1199(99)00003-6

Gul, F. A., \& Kealey, B. T. (1999). Chaebol, Investment Opportunity Set and Corporate Debt and Dividend Policies of Korean Companies. Review of Quantitative Finance and Accounting 13(4), 401-416.

Haron, R. (2018). Ownership and Debt Financing: Indonesia Evidence. In: Financial Management from an Emerging Market Perspective. https://doi.org/10.5772/intechopen.70618

Hoang, L. X., Dang, D. Q., \& Tran, T. D. (2020). The Role of Overconfident CEO to Dividend Policy in Industrial Enterprises. Journal of Asian Finance, Economics and Business, 7(7), 361-367. https://doi.org/10.13106/jafeb.2020.vol7.no7.361

Ilyukhin, E. (2017). The Determinants of Capital Structure: Evidence from Russia. Journal of Corporate Finance Research, 11(4), 54-69.

Indrajaya, G., Herlina, \& Setiadi, R. (2011). The Influence of Asset Structure, Company Size, Growth Rate, Profitability, and Business Risk on Capital Structure: An Empirical Study of Mining Sector Companies Listing on the Indonesia Stock Exchange 2004-2007 Period. Jurnal Ilmiah Akuntansi, 2(6), $1-23$. 
Issa, A. I. F. (2015). The Determinants of Dividend Policy: Evidence from Malaysian Firms. Research Journal of Finance and Accounting, 6(18). http://ssrn.com/abstract=2770541

Jabbouri, I. (2016). Determinants of corporate dividend policy in emerging markets: Evidence from MENA stock markets. Research in International Business and Finance, 37, 283-298. https://doi.org/10.1016/j.ribaf.2016.01.018

Jensen, M. C. (1986). Agency Costs of Free Cash Flow, Corporate Finance, and Takeovers Agency Costs of Free Cash Flow, Corporate Finance, and Takeovers. American Economic Review, 76(2), 323-329.

Lious, N. A. T., Irene, P. F., \& Pilar, C. F. (2015). Capital Structure's Determinants and Financial Crisis in Spain. In: SSRN Electronic Journal. https://doi.org/10.2139/ssrn.2632087

Lloyd, W. P., Jahera, S. J., \& Page, D. E. (1985). Agency cost and dividend payout ratios. Quarterly Journal of Business and Economics, 24(3), 19-29.

Long, M. S., \& Malitz, I. B. (1985). Investment Patterns and Financial Leverage. In: B. M. Friedman (Ed.), Corporate Capital Structures in the United States (pp. 325-352). Chicago, IL: University of Chicago Press.

Maldajian, C., \& El Khoury, R. (2014). Determinants of the Dividend Policy: An Empirical Study on the Lebanese Listed Banks. International Journal of Economics and Finance, 6(4). https://doi.org/10.5539/ijef.v6n4p240

Mitton, T. (2008). Why Have Debt Ratios Increased for Firms in Emerging Markets? European Financial Management, 14(1), 127-151. https://doi.org/https://doi.org/10.1111/j.1468036X.2007.00430.x

Mukhibad, H., Subowo, S., Maharin, O. D., \& Mukhtar, S. (2020). Determinants of Debt Policy for Public Companies in Indonesia. Journal of Asian Finance, Economics and Business, 7(6), 29-37. https://doi.org/10.13106/jafeb.2020. vol7.no6.029

Myers, S. C. (1977). Determinants of Corporate Borrowing. Journal of Financial Economics, 5, 147-175.

Myint, S., Lupi, A., \& Tsomocos, D. P. (2018). How Investment Opportunities Affect Optimal Capital Structure. Journal of Applied Corporate Finance, 29(4), 112-124. https://doi. org/10.1111/jacf.12266

Pettit, R. R., \& Singer, R. F. (1985). Small Business Finance: A Research Agenda. Financial Management , 14(3), 47-60.

Qamar, S., \& Ahmed Bazaz, Z. (2014). Factors Influencing Dividend Decision: A Study of Listed Companies in India. International Journal of Scientific Research and Reviews, 3(31), 40-66. www.ijsrr.org

Ressy, A. E., \& Chariri, A. (2013). Pengaruh Kinerja Keuangan terhadap Kebijakan Dividen di Bursa Efek Indonesia. Diponegoro Journal of Accounting, 2, 1-10. http://ejournal-s1. undip.ac.id/index.php/accounting

Rozeff, M. S. (1982). Growth, Beta and Agency Costs as Determinants of Dividend Payout Ratios. Journal of Financial Research, 5(3), 249-259.

Smith, C. W., \& Stulz, R. M. (2006). The Determinants of Firms' Hedging Policies. The Journal of Financial and Quantitative Analysis, 20(4), 391. https://doi.org/10.2307/2330757

Tahir, H., Rahman, M., \& Masri, R. (2020). Do board traits influence firms' dividend payout policy? Evidence from Malaysia. Journal of Asian Finance, Economics and Business, 7(3), 87-99. https://doi.org/10.13106/jafeb.2020.vol7.no3.87

Tahir, M., \& Mushtaq, M. (2016). Determinants of Dividend Payout: Evidence from listed Oil and Gas Companies of Pakistan. Journal of Asian Finance, Economics and Business, 3(4), 25-37. https://doi.org/10.13106/jafeb.2016.vol3.no4.25

Vijayakumaran, S., \& Vijayakumaran, R. (2019). Debt maturity and the effects of growth opportunities and liquidity risk on leverage: Evidence from Chinese listed companies. Journal of Asian Finance, Economics and Business, 6(3), 27-40. https:// doi.org/10.13106/jafeb.2019.vol6.no3.27

Walker, R. (2019). JPMAM finds value in emerging market dividends. Fund Selector Asia. https://fundselectorasia.com/ jpmam-finds-value-in-emerging-market-dividends/

Watts, R. L., \& Smith, C. W. (1992). The investment opportunity set and corporate financing, dividend, and compensation policies. Journal of Financial Economics, 32(3), 263-292. https://doi. org/10.1016/0304-405X(92)90029-W 